\title{
FRAGMENTOS DA MEMÓRIA DE UM POVO: AS HISTÓRIAS DE CAÇA E O BESTIÁRIO EM LEVANTADO DO CHÃO
}

RESUMO: Neste artigo, são analisadas as três histórias de caça presentes no romance Levantado do chão, narradas pelos personagens António Mau-Tempo e Sigismundo Canastro, e a presença de inúmeros animais ao longo da narrativa. Tanto as histórias de caça quanto o bestiário remontam a um vínculo com a tradição oral, característica da escrita de José Saramago, e também exercem a função de metáfora para a vida e a luta do povo alentejano.

Palavras-chave: bestiário, levantado do chão, Saramago, caça, animais.

\section{FRAGMENTS OF THE MEMORY OF A PEOPLE: THE STORIES OF HUNTING AND THE BESTIARY IN RAISED FROM THE GROUND}

ABSTRACT: The present article analyzes all the three stories of hunting, narrated by the characters António Mau-Tempo and Sigismundo Canastro, in the novel Raised from the ground, as well as the presence of countless animals throughout the narrative. Both the stories of hunting and the bestiary evoke the link to the oral tradition, peculiar to José Saramago's writing, and also function as a metaphor to the life and the struggles of the Alentejo people.

KEYWORDS: bestiary, raised from the ground, Saramago, hunting, animals.

Nós plantamos as sementes para colhermos no fim Nossos dias são preciosos e tão poucos

Todos nós colhemos o que nos é devido

Um céu de juiz que não é mais azul

Trazemos a madrugada sobre os novos ${ }^{2}$

Levantado do chão percorre a trajetória da família Mau-Tempo por quatro gerações, perpassando momentos históricos conturbados em Portugal e no mundo, que, para os trabalhadores do campo, por força de uma alienação produzida, chegam apenas como sussurros. Os Mau-Tempo são eleitos como principais atores da narrativa, mas eles representam metonimicamente o que todas as famílias que viviam no campo, em Portugal, sofriam então com a opressão do latifundiário, numa nação que não se importa com seus direitos e com uma igreja que se preocupa apenas em manter seus seguidores como "ovelhas apascentadas". Aliás, seguindo a metáfora, percebe-se no texto a grande quantidade de referências a animais, ora como símbolo para certos grupos de personagens, ora como alegoria da vida campesina. O bestiário saramaguiano possui, portanto, um enorme peso no romance e está presente em duas instâncias: nas narrativas em si e nas

\footnotetext{
${ }^{1}$ Mestranda de Lteratura Portuguesa do Departamento de Letras Vernáculas da UFRJ.

2 Trecho traduzido da música Re-education (through labor) da banda Rise Against.
} 
histórias de caça, quando a instância narrante abre espaço para que seus personagens possam contar suas histórias com suas próprias vozes.

Comecemos, então, pelas vozes que ganham lugar e finalmente se fazem ouvir.

\section{As histórias de caça}

A narrativa de Saramago tem a característica recorrente de o narrador, em terceira pessoa, que goza de uma posição de observador privilegiado, não ser totalmente onisciente e onipresente: há uma escolha de personagens que serão seguidos e, dessa forma, ele verá através de seus olhos, ou seja, os limites que esses personagens selecionados apresentam são, por conseguinte, também os limites do narrador. Como exemplo podemos citar, em Memorial do convento, o sumiço de Baltasar na narrativa após subir aos céus com a passarola, pois os olhos utilizados eram os de Blimunda, ou a Mulher do Médico, em Ensaio sobre a cegueira, que não cegou para que o narrador de Saramago, tendo seus olhos, também pudesse ver.

Esse é um aspecto da escrita de Saramago que mostra que esta não é totalizante e soberana, com um narrador que tudo sabe e tudo vê. Da mesma forma, em Levantado do chão, sem autoritarismo, o narrador principal abre mão de seu papel narrativo para dar espaço e vOz a seus personagens, com suas próprias palavras e por vezes com interrupções de um interlocutor, trazendo para a cena da escrita as estratégias de oralidade, introduzindo longas histórias dentro da história maior que é o livro e funcionando, não raras vezes, como uma espécie de mise en abyme. O conceito, largamente conhecido, vem muito bem explícito nas palavras de Dällenbach:

A mise en abyme consiste num processo de reflexividade literária, de duplicação especular. Tal auto-representação pode ser total ou parcial, mas também pode ser clara ou simbólica, indirecta. Na sua modalidade mais simples, mantém-se a nível do enunciado: uma narrativa vê-se sinteticamente representada num determinado ponto do seu curso. Numa modalidade mais complexa, o nível de enunciação seria projectado no interior dessa representação: a instância enunciadora configura-se, então, no texto em pleno acto enunciatório. Mais complexa ainda é a modalidade que abrange ambos os níveis, o do enunciado e o da enunciação, fenómeno que evoca no texto, quer as suas estruturas, quer a instância narrativa em processo. A mise en abyme favorece, assim, um fenómeno de encaixe na sintaxe narrativa, ou seja, de inscrição de uma 
micro-narrativa noutra englobante, a qual, normalmente, arrasta consigo o confronto entre níveis narrativos (DÄLLENBACH, 1976). ${ }^{3}$

Em Levantado do chão, são diversos os momentos em que o narrador dá a vez a seus personagens para que eles possam contar suas próprias histórias de vida, suas aventuras e os "causos" narrados de boca-em-boca, afinal, quem melhor para contar as alegrias e tristezas de um povo do que ele mesmo? "Não haveria, talvez, outra forma de dar voz à massa campesina senão deixando-a falar, utilizando o recurso da memória colectiva que resgata o passado quando outras formas de registo não se abriram para fixar as lembranças do tempo" (SILVA, 1989, p. 196).

Tal recurso para dar a palavra às diversas vozes silenciadas e violentadas pelos poderosos ao longo de séculos - como mostra a genealogia da família Mau-Tempo, iniciada pelo estupro da donzela que foi à fonte, cometido pelo alemão e senhor de terras Lamberto Horques - também é uma forma claramente contra-ideológica de trazer o lugar do povo sem voz para a narrativa. Saramago, ao narrar as histórias e também ao deixá-las serem narradas por terceiros, cria uma "hibridização entre o erudito e o popular" (OLIVEIRA NETO, 2010, p. 17).

Levantado do chão são retratos de memória dignos de registro que nos permitem ver o avesso real dos fatos e ver os recortes de construção que são operados no interior da história oficial. Ao apresentar tal história interconectadas [sic] às narrativas populares, Saramago recobra que ambas estão no mesmo nível, o nível da palavra; ambas são fruições repetidas e refeitas até causarem o efeito de estranhamento, o levantar-se do chão, o novo (OLIVEIRA NETO, 2010, p. 17).

Entre as várias histórias contadas ao longo da narrativa, destacaremos as de caça, que são narradas por dois personagens: Sigismundo Canastro e António Mau-Tempo. As histórias de caça remontam ao costume da tradição oral, da narrativa de "causos" contados em roda de amigos e família, do lado de fora da casa à luz das estrelas ou em uma taverna, ou ainda às "histórias de pescador", em que acontecimentos extraordinários ocorrem sempre que uma pessoa está pescando sozinha, sem ter como trazer provas do que fala. Contudo, para o público que ouve, acostumado a saborear tais contos e também a contálos, não importa se é de mentira ou de verdade que se fala, afinal, como diz o próprio

\footnotetext{
3 Retirado do E-Dicionário de termos literários, do professor e escritor Carlos Ceia. Disponível em:

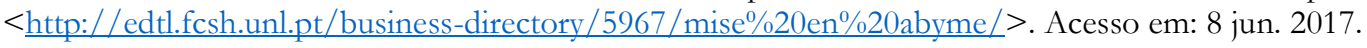


António Mau-Tempo, "Alguma vez terá de acreditar naquilo que nunca ouviu" ( $L C{ }^{4}$ p. 284), pois "São os homens feitos de maneira que mesmo quando mentem dizem outra verdade, e se pelo contrário é a verdade que querem lançar da boca para fora, vai sempre com ela uma forma de mentir, mesmo não havendo o propósito" (LC, p. 284).

Além desse vínculo com a tradição, as narrativas de caça no romance têm enorme importância textual por se transformarem em metáforas sobre o povo alentejano e a luta de classes, e tal qual as histórias populares, têm, ainda, a função de trazer explicações e ensinamentos (OLIVEIRA NETO, 2010). "Elas exercem uma função metafórica, que ultrapassa a própria seriedade do que é dito, para se transformarem num debate modelar, onde o poder é colocado em questão e o seu representante, afastado e vencido" (CERDEIRA, 1989, p. 246).

A primeira história que selecionamos é a de Sigismundo Canastro, sobre um dia de caça em que um grupo de caçadores vinha acompanhado pelo cão Constante. De repente, o cão avista uma perdiz e corre para dentro da mata para matá-la e trazê-la para seu dono, que, contudo, não o consegue encontrar. Dois anos depois, Sigismundo encontra o esqueleto de Constante e da perdiz na posição de uma luta eterna, em que um, resistentemente, foge, enquanto o outro está sempre a atacar. Ora, essa história, entre todas as outras, representa bem a luta entre os trabalhadores do campo com os latifundiários, em que o cão seria os primeiros e a perdiz, os últimos.

A perdiz é uma ave de canto desafinado e, por isso, desagradável a quem a ouve, apesar de sua aparência ser bela. É curioso notar que, ao pesquisar o significado da perdiz para os cristãos, encontra-se uma conotação negativa, de maldade, tentação, perdição ou até mesmo do próprio demônio. ${ }^{5}$ Assim, como os latifundiários, sua aparência é inofensiva, mas há algo de ruim por trás dessa máscara que seu canto acusa. O cão, por outro lado, é aquele que é fiel, afável, mas que defende os seus e ataca aquele que os importuna. Tal qual seus antepassados, os lobos, os cães são capazes de trabalhar para um conjunto, uma matilha. Esses são os trabalhadores e a ideia geral do comunismo que nos é apresentada neste livro. O nome do cão também não é sem importância: Constante é firme, persistente e luta até o fim de sua existência contra aquele que representa sua opressão.

\footnotetext{
${ }^{4}$ Para facilitar as citações que se referem ao romance Levantado do chão, colocaremos a abreviação $L C$ seguida da página.

${ }^{5}$ Disponível em: $<$ http://www.significadodossimbolos.com.br/busca.do?simbolo=Perdiz $>$.
} 
A história do cão e da perdiz é ainda citada em outras passagens do livro, em duas situações cruciais: a primeira, no interrogatório de João Mau-Tempo pela PIDE, quando as perguntas repetidas e intermináveis são ditas de forma rude por guardas que entram e saem todo o tempo, mas "a vítima é sempre a mesma", constante. Por três dias deixaram João Mau-Tempo em pé, “de estátua", e a luta parecia ser eterna, tal qual a batalha do cão e da perdiz, evocada pelo personagem no momento da tortura que lhe era imposta. Os torturadores diziam: "lembra-te da tua família e da liberdade". E "João Mau-Tempo lembra-se da família e da liberdade", como o policial ordenara, mas também se lembra de algo mais, de lutar: "lembra-se da história do cão e da perdiz, contada por Sigismundo Canastro", comenta o narrador. Cansado, João Mau-Tempo já lembrava fisicamente o próprio cão e se torna, nas palavras do narrador, um "esqueleto de cão marrado contra a perdiz" (LC, p. 249) - "marrado", isto é, batendo, atacando, a perdiz.

O segundo momento em que essa história é evocada situa-se no fim do livro, quando todos os camponeses do Alentejo se levantam, tanto os vivos quanto os mortos, tanto os humanos quanto os animais. E o cão aparecerá em posição privilegiada, metáfora de todos os resistentes que chegam enfim ao dia da revolução: "E à frente, dando os saltos e as corridas da sua condição, vai o cão Constante, podia lá faltar, neste dia levantado e principal" (LC, p. 366). Constante, representação de uma época de resistência, junto com tantos outros que resistiram à sua própria maneira - seja sofrendo, passando fome, cuidando da família por menor que sua condição fosse, seja torturado como Germano Santos Vidigal, ou sonhando e esperando que o tormento passasse -, foi lembrado justamente no final do último parágrafo desse longo livro de sofrimentos, mostrando que cada personagem, cada pessoa do Alentejo, teve sua importância no processo da revolução.

A segunda história de caça contrapõe dois animais que muito se assemelham, são da mesma família, mas se diferenciam em alguns aspectos. Na primeira parte da história, António Mau-Tempo conta sobre as curiosidades da lebre que lê jornal e dos caçadores que, se aproveitando dessa curiosidade, usam o jornal com uma pedra lisa e a pimenta, cujo cheiro faz a lebre espirrar, bater com a cabeça na pedra e, consequentemente, morrer. Sua curiosidade foi sua perdição. Logo em seguida, António passa a contar de quando foi caçar coelhos e não pôde usar desse mesmo truque usado com a lebre, pois, assim como os gatos, "os coelhos são bichos sem qualquer espécie de curiosidade" (p. 283). 
$\mathrm{Na}$ natureza, a diferença entre lebre e coelho é que a primeira tem longas orelhas, é mais rápida, possui maior resistência e patas traseiras grandes. Além disso, seus filhotes já nascem peludos e enxergando, enquanto os coelhos nascem cegos ${ }^{6}-$ o que é bastante significativo para a história. As lebres seriam os camponeses levantados, que se reúnem, fazem greve e reclamam mudanças, e, por isso, estão mais sujeitos à morte causada pelo podengo, o cão caçador. Essa comparação nos é apontada sutilmente pela própria narrativa, antes da história começar:

Quem por tais lugares se perde, acaba por distinguir entre a paisagem e as palavras que lá estão, e é por isso que às vezes damos com um homem parado no meio do campo, como se, indo no seu passo e passeio, de repente alguém o tivesse retido pela mão, ora ouça cá, é certo e garantido que está a ouvir palavras, casos, voltas, foi ter ali passado no momento próprio e ser ele a pessoa esperada, solta-se o fluxo aéreo e tanto pode vir o sucesso magnífico do cão Constante como a verdadeira demonstração da curiosidade das lebres, explicada por António MauTempo e comprovada por todos os sonhos de Sigismundo Canastro, na falta de mais alguém que de seus sonhos quisesse falar (LC, p. 282).

Se as lebres são os homens apanhados por sua curiosidade - assim como João MauTempo é preso pela PIDE por apanhar um panfleto comunista no chão e como diversos outros homens são presos por se manifestarem contra a alienação -, os coelhos, por outro lado, seriam os camponeses ignorantes de seu estado, que não possuem curiosidade, pois, para eles, saber das notícias e ver uma nuvem no céu significa o mesmo: que suas vidas não mudarão. A nuvem ainda é um pouco mais atrativa, pois "da nuvem chove e do jornal não" (LC, p. 283). Sem falar que, em 1945, período anterior ao que as histórias de caça são contadas,

podia-se estimar que, dos oito milhões de portugueses, contrariamente, aos resultados viciados das estatísticas oficiais, 60 por cento não sabiam ler nem escrever; só 15 por cento sabiam ler; apenas 20 por cento tinham frequentado regularmente a escola primária e obtido o respectivo diploma; e só 5 por cento, que poderiam ser considerados instruídos, tinham cursos secundários ou grau universitário (FIGUEIREDO, 1976, p. 108).

Cinco anos depois, os índices eram ainda enormes: 50\% dos portugueses eram analfabetos. Nos anos 70, um em cada quatro portugueses não sabia ler e, até hoje, a região

6 Disponível em: <http://www.manualdomundo.com.br/2014/01/qual-a-diferenca-entre-coelhos-elebres $/>$. 
do Alentejo é a que mais sofre: mais de $9 \%$ de analfabetismo ${ }^{7}$. Portanto, de fato, era mais interessante saber do tempo, que influenciava as colheitas, do que de um pedaço de papel que nada lhes dizia.

Isso nos leva à última história, que apenas de coelhos se trata: António Mau-Tempo armara um plano para matar coelhos sem que precisasse de chumbo, pois, tal como na história anterior, não tinha dinheiro para comprá-lo. Usando uma esfera de aço, pretendia prender o animal sem que precisasse estragar a pele ou a carne com tiros de cardas. Acertou o que ele chama de o Pai dos Coelhos, "[fazendo] de conta que era uma perdiz" (LC, p. 286), e conseguiu prendê-lo pelas orelhas. Contudo, em vez de matá-lo, o salva, não por compaixão ou interesse futuro, mas por honradez, pois "acertar-lhe na orelha não foi pontaria, foi acaso, e sorte, e o pai dos coelhos não podia morrer por um acaso" (LC, p. 286). António Mau-Tempo soltou-o por saber que ele merecia, como a adiantar involuntariamente a metáfora futura do narrador que o vê um dia a ele, António MauTempo, a se soltar e fugir de um cruel destino que marcava a todos.

O latifúndio é um campo de estrepes e em cada um deles está um coelho a espernear, com a orelha furada, não por obra de tiro mas por nascença, ficam ali toda a vida, lavram o chão com as unhas, com os excrementos adubam-no, e se alguma erva há, comê-la é só aonde o dente puder chegar, com o focinho bem rasteiro ao chão, enquanto ao redor andam passos de caçadores, morro, não morro. Um dia, António Mau-Tempo soltou-se da sebe e atravessou a fronteira, por cinco anos o fez, uma vez em cada um, foi para terras de França, norte da França, Normandia, mas ia levado pela orelha, filado pelo buraco da necessidade [...] (LC, p. 287).

No entanto, se conseguiu fugir do destino dos coelhos, António Mau-Tempo não chega a modificar seu destino e a tornar-se lebre, pois mudou-se de país, mas não de condição, ao deixar o trabalho sofrido no latifúndio português para passar ao latifúndio francês. Mudara apenas de estepe.

\section{2. $\mathrm{O}$ bestiário}

Essas três histórias aqui apresentadas servem para afirmar "pontos diversos dentro daquilo que o narrador está naquele momento expressando" (MARTINS FILHO, 2012, p.

\footnotetext{
${ }^{7}$ Informações retiradas da matéria "Taxa de analfabetismo em Portugal ainda é das maiores na Europa" do jornal Expresso. Disponível em: < http://expresso.sapo.pt/sociedade/2016-09-03-Taxa-de-analfabetismo-emPortugal-ainda-e-das-maiores-na-Europa $>$. Acesso em: 10 jul. 2017.
} 
205), assim como a presença de diversos outros animais que transbordam deste romance saramaguiano. Além da perdiz, da lebre e do coelho, outros animais possuem enorme importância na narrativa, não apenas nas histórias de caça contadas pelos personagens, mas na história principal:

Suas aparições serão sempre utilizadas como uma câmara de eco que reforça os conteúdos e atributos humanos descritos, e sobre os quais o narrador insiste que prestemos atenção. Logo, longe de animais em si mesmos, os conteúdos manifestos pelos mesmos só encontram significação pelo conjunto da cena humana que o narrador busca, para além do descrever, construir. Assim sendo, este será um bestiário de símbolos antropomórficos de atitudes, sentimentos ou ações através dos quais o texto destaca ao olhar do leitor como um dos itens da paisagem a ele apresentada (MARTINS FILHO, 2012, p. 205).

Gabriel Giorgi, em seu estudo Formas comuns: animalidade, literatura e formas politicas, para escrever sobre a presença dos animais na literatura, primeiro contextualiza as diferentes significações que os animais possuem em diferentes épocas, territórios, formas e sentidos. Ao longo do tempo, uma das atribuições do animal é com o lado selvagem, ameaçador, bárbaro e indisciplinado dos homens, a de "pura alteridade do homem" entanto, tal visão "começ[ou] a funcionar de modos cada vez mais explícitos como um signo político" (GIORGI, 2016), trazendo distinções e oposições entre os homens e as coisas: "natural/cultural, selvagem/civilizado, biológico/tecnológico, irracional/racional, vivente/falante, orgânico/mecânico, desejo/instinto, individual/coletivo etc.”. Ou seja, com essas divisões tão maniqueístas, acaba-se "coisificando" os corpos, dividindo as pessoas que são sacrificáveis e aquelas que são dignas de serem salvas. O homem acaba se tornando "um animal em cuja política está em questão a sua vida de ser vivente" (FOUCAULT, 1988). A questão colocada por Foucault e reposta por Giorgi é: como se decide quais corpos são descartáveis e quais não são? A resposta é simples: há uma hierarquização desses corpos, e suas posições nessa escala são definidas pelo biopoder. ${ }^{9}$

Em particular, o desenvolvimento e o triunfo do capitalismo não teria sido possível, nesta perspectiva, sem o controle disciplinar efetuado pelo novo biopoder, que criou para si, por assim dizer, através de uma série de tecnologias apropriadas, os "corpos dóceis" de que necessitava (AGAMBEN, 2007, p. 11).

\footnotetext{
8 Texto de Gabriel Giorgi em espanhol, El animal comunista", traduzido livremente. Disponível em: < http://hemisphericinstitute.org/hemi/pt/e-misferica-101/e101-dossier-el-animal-comunista>.

9 "Biopoder" é um termo cunhado por Michel Foucault. Designa o controle dos Estados modernos sobre os corpos e as populações.
} 
Ora, essa é exatamente a questão em Levantado do chão. O Latifúndio, o Estado e a Igreja formam o biopoder. "São vozes de falares idênticos que se unem em prol da classe dominante" (SILVA, 1989, p. 197) e com um controle total dos corpos dos trabalhadores da terra: pelo trabalho, que toma a maior parte do seu tempo, pois levantam-se quando ainda é noite e chegam em casa apenas na hora de dormir, mal paga o suficiente para sua sobrevivência e ainda força seus corpos a extremos absurdos; pelo governo que deveria velar sobre suas vidas, impedindo que esses abusos acontecessem; e pela igreja que lhes toma o único dia de descanso, o domingo, apenas para ouvirem mais sobre o modo como devem obedecer às outras duas entidades e mais a Deus. A religião, que deveria ser um refrigério para suas almas, um conforto, torna-se o lugar da confirmação da opressão e a garantia dos "corpos dóceis". "O sonho desses discursos é a manutenção do status quo, o imobilismo. Apoiado pelas leis divinas que a Igreja traduz e pelas leis do direito dos homens que o Estado impõe, o Latifúndio sente-se forte para dominar, fazendo com que essa dominação não seja tida como violenta, mas como legal” (SILVA, 1989, p. 197). A L.E.I., ${ }^{10}$ portanto, possui seus corpos físicos e seus espíritos. Além disso, o atraso tecnológico apenas dificultava ainda mais a vida dos trabalhadores braçais: "Os camponeses da região viviam numa idade pré-tecnológica, usando métodos arcaicos de agricultura que pouco tinham mudado em séculos. Viviam em muitos casos numa condição semi-humana, semianimal" (FIGUEIREDO, 1976, p. 12). Dessa forma, sem qualquer tipo de saída ou elucidação de sua situação, os camponeses seguem longe do topo da hierarquia, parecendo ser apenas "gente suja, faminta e doente, [que] perdem contornos humanos, reduzem-se a bestas de carga, formigas ou cães a ladrar" (SILVA, 1989, p. 202). Assim, não é difícil deduzir quais corpos são considerados os descartáveis...

Saramago vai ao encontro dessa crítica, mas também segue de encontro a ela ao colocar todos os homens sendo representados por animais. O primeiro sobre o qual iremos nos deparar é o cão. Apesar de já ter sido citado, o cão é o animal que mais vezes surge em Levantado do chão, principalmente fora das histórias de caça, sendo citado 76 vezes ao longo de toda a narrativa. Mas é interessante notar como ele não tem sempre a mesma conotação que o cão Constante. Ele aparece com 5 diferentes atribuições:

\footnotetext{
${ }^{10}$ Essa organização das três entidades formando a sigla L.E.I. (Latifúndio, Estado e Igreja), tal como a Santíssima Trindade, é do professor Jorge Fernandes da Silveira. Cf. SILVEIRA, Jorge Fernandes da. "Os portugueses". Folha de S. Paulo, São Paulo, 22 abr. 1988. Folhetim, p. 2-5.
} 
a) Metafórica: como o cão Constante e os cães que latem quando a guarda entra na cidade (LC, p. 103);

b) De comparação positiva: quando, chegando ao fim da narrativa, os camponeses, exigindo seus direitos de trabalhadores, parecem rosnar, ladrar e ameaçar morder os formadores da L.E.I. Isso é muito bem descrito e ironizado na página 306:

[...] e tenha cuidado ao sair, não lhe mordam os cães. Quando o padre Agamedes assoma à porta do prédio, solta trémula a sua voz aguda e pergunta, Estão presos os cães, e há alguém que lhe responde indiferente, Estes estão, e dito assim ficamos sem saber que cães estão soltos e que cães estão presos, mas o padre Agamedes tem fé que lhe defenda a informação os interesses da barriga da perna, e sai para o pátio, é verdade que os cães estão presos, mas quando atravessa o portão e vem para a rua, está um juntamento de gente, não é que ladrem, era o que faltava, ladrarem homens, porém se este murmúrio não é como o rosnar dum cão, perca eu o nome que tenho [...] (LC, p. 306, grifos nossos).

c) De comparação negativa: em certos trechos, há lamentos e acusações de que os latifundiários, capatazes, a igreja e o governo tratem os camponeses como cães, ou seja, de forma desumana ou indiferente - o que nos remete aos pensamentos de Giorgi, Foucault e Agamben. Na página 88, quando António Mau-Tempo ainda era uma criança, um "faz tudo" nos pequenos serviços da terra, o narrador censura: "e António Mau-Tempo, vassourinha de varrer, girava em redor da vara como se fosse, ele, cão pastor". No mesmo capítulo mais adiante, após ser mandado embora do serviço, João, seu pai, toma suas dores e reclama: "e ele é que tem de ser o cão, correr e cercar tudo, o rapaz não é carocha para lhe pôr o pé em cima" ( $L C$, p. 89). Em um capítulo mais adiante, para ilustrarmos um pouco mais, depois da saída de João da cadeia, uma voz crítica - não sabemos se pertence ao narrador, a João, a Maria da Conceição, sua irmã, ou, na mente de João, aos patrões de Maria - diz: "não se pode deixar um cristão a dormir na rua como os cães sem dono" (LC, p. 262);

d) De inferioridade: Neste ponto, os cães e os homens seriam não só comparados como hierarquizados, tal como nos esclarece Agamben em Homo Sacer, porém, no romance, existe uma hierarquia dentro do mundo animal, assim como existe entre os homens. Os caninos, ao longo do livro, não são relacionados somente com os trabalhadores da terra, mas também com os vendedores, os feitores e os guardas.

Os guardas e os torturadores de Germano Santos Vidigal são, assim como todos dessa cadeia, cães, mas não um cão vira-lata ou, como diz na passagem em que João MauTempo procura abrigo, "sem dono". São “figura[s] do poder, figura[s] híbrida $[\mathrm{s}]$ - meio 
animal, meio homem" (SILVA, 1989, p. 221), cães de raça com "duas pernas e nome de homem" (LC, p. 90), podengos cujo dono é a L.E.I. O podengo português é um animal de caça, usado principalmente na caça de coelhos - o que é bastante significativo, sendo o trabalhador alienado representado pelo coelho, como vimos anteriormente. "porque estará esse podengo a mostrar os dentes [...] mas se eu arranjar uma desculpa, estou com a pontada, ou tenho de ir pôr uns paus na coelheira, não vai acreditar, sei lá se depois me vem prender" (LC, p. 91, grifos nossos).

Os comerciantes e cobradores de fiado, por sua vez, são cachorros que perseguem, enfurecidos, os outros cães menores e mais fracos que não têm o que comer e nem como pagar o pouco que comem. "Ladram por toda esta terra os cães, ouvimo-los às portas, vêm atrás de quem não pagou, mordem-lhe as canelas, mordem-lhe na alma, e o merceeiro vem à rua e diz para quem o quer ouvir, Diga lá ao seu marido, o resto já se sabe” ( $L C$, p. 82). Perseguem e cobram porque também precisam comer; é a lei do mais forte.

Já os feitores, estariam no mesmo patamar que os trabalhadores, mas a forma que encontraram de mudar de vida é a de se virarem contra seus iguais e a corrupção. São os oprimidos que, tal como os comerciantes, tornaram-se opressores. Essa atitude dos feitores e dos comerciantes é muito bem explicada por Paulo Freire na Pedagogia do oprimido:
os oprimidos, em lugar de buscar a libertação, na luta e por ela, tendem a ser opressores também, ou subopressores. A estrutura de seu pensar se encontra condicionada pela contradição vivida na situação concreta, existencial, em que se "formam". O seu ideal é, realmente, ser homens, mas, para eles, ser homens, na contradição em que sempre estiveram e cuja superação não lhes está, clara, é ser opressores. Estes são o seu testemunho da humanidade.
[...] São eles e ao mesmo tempo são o outro introjetado neles, como consciência opressora. Sua luta se trava entre serem eles mesmos ou serem duplos. Entre expulsarem ou não ao opressor de "dentro" de si (FREIRE, 1987, p. 17, 19).

O narrador de Saramago sabe muito bem disso e, por isso, explica em outras palavras: "O feitor é o chicote que mete na ordem a canzoada. É um cão escolhido entre os cães para morder os cães. Convém que seja cão para conhecer as manhas e as defesas dos cães. Não se vai buscar um feitor aos filhos de Norberto" (LC, p. 72).

E, por último, os cachorros propriamente ditos, os animais não metafóricos. Ainda eles estão acima dos camponeses. Em mais de uma passagem, os personagens dizem ser "menos do que os cães", pois estes "comem todos os dias" e "ninguém seria capaz de 
deixar um animal passar fome" (LC, p. 360). Abaixo, uma pirâmide de hierarquia que resume o acima explicitado:

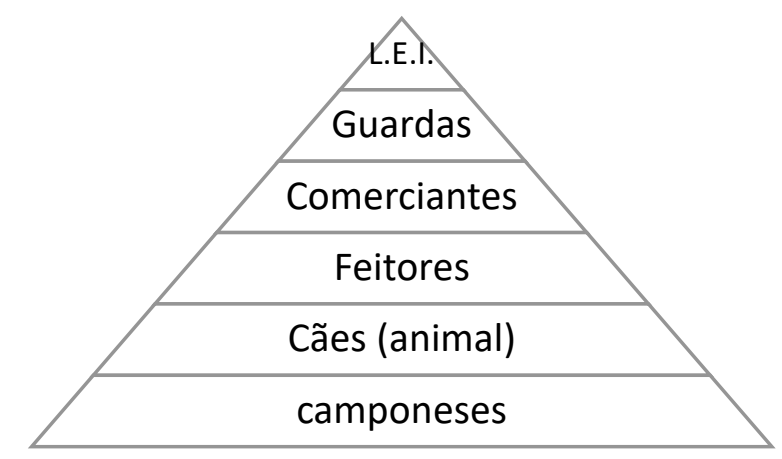

No topo da pirâmide está a L.E.I., que não é comparada aos cães, mas, sim, a outro animal que, vez ou outra, também é citado como a guarda e os feitores: os gatos (citados 70 vezes). Gatos, no Antigo Egito e em diversas outras culturas, são animais adorados e reverenciados como deuses, símbolos de poder além de qualquer mortal. Na narrativa, são postos como preguiçosos, que ficam deitados ao sol enquanto os outros fazem suas atividades por eles e que afiam as unhas apenas aguardando o momento certo de usá-las: "brincam o gato e o rato, como este é comido por aquele. Porque a questão, a única questão que importa, é saber a quem aproveita realmente a inocência primeira do jogo, por exemplo, deste brincar que nunca foi inocente" (LC, p. 74), pois "afinal a lei do latifúndio são os homens mesmos que continuam a fazê-la para que continuem a cumpri-la os mesmos" (LC, p. 357). A lei é para

eu Manuel Espada, eu António Mau-Tempo, eu Sigismundo Canastro, eu José Medronho de cicatriz na cara, eu Gracinda Espada e minha filha Maria Adelaide [...], eu homem e mulher deste latifúndio, herdeiro de não mais que petrechos de trabalho se não se gastaram ou partiram antes, como partido e gasto vou eu estando, voltou a desolação aos campos do Alentejo, voltará a correr sangue (LC, p. 357).

e não para os Bertos, pois “ainda hoje não se sabe muito bem se um gato é um bicho" (LC, p. 149). Se os camponeses são, para os Bertos e os agentes do poder, menos do que animais, para Saramago, estes que são menos do que bichos.

É interessante perceber que o nome do homem que comanda um grupo de assaltantes de mercadorias dos latifundiários é José Gato. José Gato, roubando apenas dos ricos, como faria Robin Hood, recusa-se a roubar pessoas pobres. Essa revolta individual não funciona como revolução, mas seu código de conduta transvia o poder estabelecido pelo latifúndio e funciona como uma forma de atingir a dignidade (SILVA, 1989). O animal 
usado para seu apelido seria, portanto, não apenas um indicativo óbvio de esperteza, agilidade e do adjetivo "gatuno", como também uma ironia com os gatos que representam os que estão acima da lei. Ele também faz a sua lei, mas uma que vai de encontro à da L.E.I.

Passaremos agora para o animal que, apesar de não ser o mais citado ao longo da narrativa (47 vezes), é o de maior importância dentro do romance. Conhecida por sua resistência, persistência e capacidade de sobrevivência, o que torna fortes as formigas não é a força bruta, mas, sim, sua habilidade de suportar coisas 20 vezes mais pesadas que seu próprio peso - a formiga (saúva) é o quarto animal mais forte de todos, ficando na frente do elefante e até do próprio homem ${ }^{11}$-, sua característica de trabalhadora eficiente e incansável e sua estrutura social, em que as necessidades da colônia são mais importantes do que as individuais. "É impossível exterminar as formigas, porque elas formam um rizoma animal do qual a maior parte pode ser destruída sem que ele deixe de se reconstruir" (DELLEUZE; GUATTARI, 1995, p. 17). Por todas essas qualidades, não é à toa que Saramago elege esse pequeno, mas incrível animal para ser alegoria, assim como os cães, dos camponeses de Levantado do chão. No entanto, diferentemente dos cães, que possuem um símbolo ambivalente e representam diversas camadas da sociedade rural do livro, as formigas estão ali para simbolizar somente os trabalhadores.

Curioso é notar que, em todo o livro, elas aparecem entre descrições de suas habilidades ( $L C$, p. 45), metáforas - "Porém, as formigas ganharam. No lusco-fusco da tarde juntaram-se os homens na praça e os feitores vieram, secos e de poucas palavras, mas rendidas" (LC, p. 147) - e comparações - "magotes de gente escura pelas estradas [...] como um carreiro de formigas pretas" (LC, p. 145) - com os camponeses, até terem personalidade própria, sendo sua visão a privilegiada para guiar a visão do narrador, como ocorre no caso de tortura de Germano Santos Vidigal. Tão trabalhadoras quanto os camponeses, elas observam assustadas e compadecidas Germando Santos Vidigal apanhar até a morte, cair várias e várias vezes, e se indignam ao ver o "Doutor Pilatos" atestar sua morte como suicídio.

Elas se indignam ao ver a injustiça contra Vidigal e, de vez em quando, uma para e levanta a cabeça como os cães para ver o que ocorre no mundo, assim como os homens-

11 Disponível em: <http://mundoestranho.abril.com.br/mundo-animal/qual-o-animal-mais-forte-doplaneta/>. 
lebres que se deixam parar no campo e na estrada pelas notícias - e, por isso, algumas acabam por morrer. É interessante notar que, por dez vezes, variações dessa frase, "formigas que levantam a cabeça como cães", surgem no texto, sendo cada vez mais frequente e também cada vez maior a quantidade de formigas que aderem a essa ação quando a narrativa da cena vai chegando ao fim, pois se as formigas são todos os trabalhadores oprimidos pela L.E.I., as que levantam a cabeça como os cães, algo que não seria possível de ser feito por esses pequenos insetos, são os trabalhadores levantados, que agora não mais aceitam que lhes esmaguem o corpo: se avolumam e atacam de volta aqueles que os oprimem.

E, por último, não podemos deixar de rapidamente trazer o "verdadeiro autor da poesia", como Teresa Cristina Cerdeira o chama (1989, p. 261), o milhano. Milhano é o nome vulgar de vários tipos de aves de rapina. É essa ave que Saramago escolhe como seus olhos para poder observar, de cima, como uma câmera captando em plano geral, a revolução dos camponeses, pois o número era tão grande que apenas do alto se poderia narrar. No parágrafo anterior, são citados anjos, mas não poderiam ser os anjos a captarem a cena, seres imóveis que nunca fizeram mais do que observar os camponeses sofrerem; eles seriam antes aqueles que somente observam esse momento épico de levante. $O$ milhano, animal como animais já foram aqueles homens, só ele poderia ser o "narradorpoeta" daquele momento histórico. É interessante que a palavra "milhano" nos faz recordar de outro narrador de causos do romance que ao Levantado do chão se segue. No Memorial do convento, encontramos um certo Manuel Milho que narra sabedorias, histórias e revoltas da vida dos silenciados pela História.

Além desses animais aqui trabalhados, diversos outros entram nessa lista de bestiário de Levantado do chão: as ovelhas apascentadas como os homens; os cardumes de peixe; os porcos; o cavalo Bom-Tempo que aparece nos sonhos de João Mau-Tempo um pouco antes de ele "se levantar" - literal e metaforicamente -; vagalumes que, tal qual a estrela guia que Deus enviou aos três reis magos, iluminam o caminho de Manuel Espada até em casa para ver a filha, Maria Adelaide, que acabara de nascer; bois; carneiros; polvos; águias; moscas; além dos "meio-animais" como os lobisomens, que não são meio homem, meio lobo, mas, sim, porcos e galinhas.

\section{Conclusão}


É através dessa animalização que Saramago primeiro traz todos, camponeses, latifundiários, Estado, Igreja, guardas, comerciantes e feitores, para um mesmo patamar para, depois, inverter a hierarquização imposta pelo biopoder. Enquanto os agentes do poder tornam-se menos do que "bicho" - expressão mais vulgar que "animal" -, os trabalhadores são formigas e coelhos silenciados, que passam a lebres apanhadas e cachorros vira-latas, para, em seguida, tornarem-se cães que ladram e rosnam, para, por fim, serem pessoas, homens e mulheres, que falam, cantam, dançam e enfim imobilizam e silenciam seus opressores, resgatando, dessa forma, o seu lugar na história. É assim que conquistam sua voz enquanto os demais "nem falando, nem cantando, nem calando, nem chorando, estão Norbertos e Gilbertos ausentes, para onde foram, sabe-se lá. A guarda não sai do posto, os anjos varrem o céu, é dia de revolução, quantos são” (LC, p. 364).

\section{Referências bibliográficas}

AGAMBEN, Giorgio. Homo Acer: o poder soberano e a vida nua. Trad. Henrique Burigo. Belo Horizonte: Ed. UFMG, 2007. v. 1.

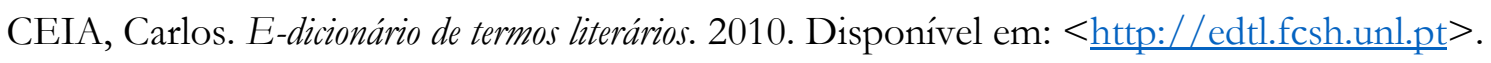
Acesso em: 10 jul. 2017.

DELEUZE, Gilles; GUATTARI, Félix. Mil platôs: capitalismo e esquizofrenia. Trad. Aurélio Guerra Neto e Celia Pinto Costa. São Paulo: Ed, 34, 1995.

FIGUEIREDO, António de. Portugal: 50 anos de ditadura. Rio de Janeiro: Civilização Brasileira, 1976.

FOUCAULT, Michel. História da sexualidade: a vontade de saber. Trad. Maria Thereza da Costa e Albuquerque e J. A. Guilhon Albuquerque. Rio de Janeiro: Graal, 1988. v. 1.

FREIRE, Paulo. Pedagogia do oprimido. Rio de Janeiro: Paz e Terra, 1987.

GIORGI, Gabriel. Formas comuns: animalidade, literatura, biopolítica. Trad. Carlos Nougué. Rio de Janeiro: Rocco, 2016.

MARTINS FILHO, Alcindo Miguel. Lendo José Saramago: Levantado do chão. Joinville: Clube de Autores, 2012.

OLIVEIRA NETO, Pedro Fernandes de. "Fractais para uma leitura sobre o popular em Levantado do chão, de José Saramago". Labirintos, Feira de Santana: Ed. Uefs, v. 7, p. 1-19, 2010. 
PRAXEDES, Walter. "Oralidade e cultura popular na escrita de José Saramago”. Revista Espaço Acadêmico, 2011. Disponível em: < https://espacoacademico.wordpress.com/2011/02/09/oralidade-e-cultura-popular-naescrita-de-jose-saramago/>. Acesso em: 10 jul. 2017.

SARAMAGO, José. Levantado do chão. Rio de Janeiro: Bertrand Brasil, 2010.

. Ensaio sobre a cegueira. São Paulo: Companhia das Letras, 2011.

. Memorial do convento. São Paulo: Companhia das Letras, 2013.

SILVA, Teresa Cristina da. José Saramago - entre a história e a ficção: uma saga de portugueses. Lisboa: Publicações Dom Quixote, 1989. 